\title{
People From The Past Marilyn Samuel
}

\author{
Editor's Note: As we commemorate the $25^{\text {th }}$ Anniversary of Rangelands mag- \\ azine, we pay tribute to SRM members who have helped shape the \\ profession of rangeland management.
}

\section{By Kindra Gordon}

Marilyn Samuel joined the Society for Range Management (SRM) in 1974, while working for USDA, ARS in Cheyenne, WY. She recalls, "The mission of the station changed to range management. Although my training was not in range management, the mission change allowed me to apply my background in plant taxonomy and ecology to the research. Joining SRM was a natural augmentation to my new research direction."

Prior to this change, Samuel had worked as a botanist (research assistant) at the High Plains Grasslands Research Station in Cheyenne since 1966, working for a plant pathologist on bacterial canker (Corynebacterium michiganense) of tomatoes, pathology testing; breeding of resistant tomato lines. She also worked for a horticulturist on small fruit (strawberry and raspberry) breeding and tetraploid carnation breeding and evaluation.

Then from 1974 to 1988 , Samuel's research objectives focused on determination of effects of environmental and biotic factors on plant species distribution, composition, and productivity of ranges and pastures as well as monitoring the reaction of plant and plant communities to environmental and management practices. Specific research included:

1) effect of grazing systems on basal cover of plant species,

2) growth responses of blue grama to varying levels of competition,

3) botanical composition and productivity changes from yearly, low-rate nitrogen fertilization, and

4) species dynamics following disturbance.

As a SRM member, Samuel has held several leadership positions over the years. She has been in- volved in the Information and Education (I\&E) Committee in her Section as well as at the Society level and chaired the I\&E committee in 1981 and 1982. She served as the annual meeting publicity chair in 1979 and the summer meeting publicity chair in 1986. Samuel was elected to the SRM Board of Directors from 1987 to 1989.

Samuel has been a dedicated member of the Rangelands Editorial Board, which she continues to serve on today. When asked what purpose Rangelands magazine has served in the past, and what it should accomplish/become in the future, Samuel says, "I have been on the Rangelands editorial board since Danny Freeman was editor, except during the time I was on the Board of Directors. One of the goals for Rangelands that has been talked about a lot of that time was to have Rangelands become a magazine of broader appeal especially outside the Society. Unfortunately, a successful strategy for this goal has not been found."

But, she adds, "A major goal of Rangelands has always been to present a broad sampling of subjects. I believe we have succeeded. I feel Rangelands has grown into a professional looking magazine in the journalistic sense. The format has changed with the changes in the styles of the times. This has occurred with the help of many people. I remember when those of us on the editorial board were almost giddy at the news of an issue with color pictures. Now we have many color photos including the great covers."

Samuel says, "A personal goal of mine has been to get authors to write in a 'popular' style not a 'scientific' style. We have some authors who consis- 
tently submit interesting, well written, popular-style articles that need little editing."

"I believe we need to continue with these goals and make Rangelands the best we can, then always try to make it better," she adds.

Looking back on the last 25-30 years, Samuel says one of the prominent changes she has noted is that more women have entered into what were previously considered "male professions."

She notes, "This change has been seen in society in several areas and is not unique to the range profession. During my high school and college years, science and math classes were dominated by males. When I attended my first section and society meetings a similar ratio was present. There were very few women working in the profession, but the increase in women could be anticipated by the number of women in the student group. As society evolved there was a corresponding evolution in the Society for Range Management."

She relays this story: When I first attended SRM meetings, I would walk up to a couple of male scientists, whom I knew. They would often quit talking about their research as if to see what I wanted to talk to them about. As more women became involved, they would say hello and continue talking about their research. I am happy to say that as the female population increased, the men included us into the "family."

She adds, "As I think about my professional 'family,' I have been lucky to have people who have encouraged and helped me along in my profession and in my work in the society. My mentors have been supervisors, researchers in and out of my agency, and SRM leaders and members."

"When I read scientific articles and go to meetings now, I am delighted to see so many dedicated members, members who are knowledgeable and professional in their jobs, members of both genders," Samuel says.

Marilyn Samuel now resides in Lehigh Acres, Florida. She adds this comment, "Why am I included in this group of SRM 'movers and shakers'? It is not because I set out to move or shake. I did not set out to be the first woman to be elected to SRM office. I was asked to run and I did."

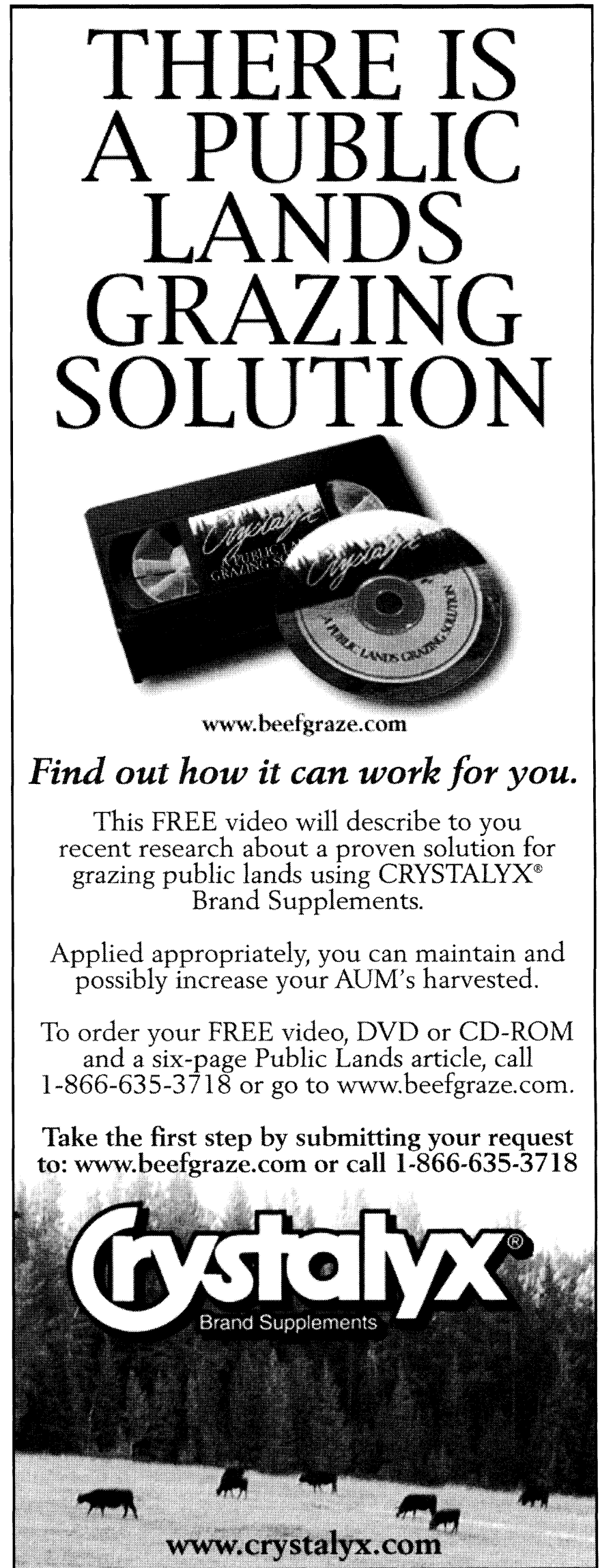

